\title{
Piezoelectric and Dielectric Properties of Low Temperature Sintered $\mathrm{Pb}\left(\mathrm{Mn}_{1 / 3} \mathrm{Nb}_{2 / 3}\right)_{0.02}\left(\mathrm{Ni}_{1 / 3} \mathrm{Nb}_{2 / 3}\right)_{0.12}\left(\mathrm{Zr}_{\mathrm{x}} \mathrm{Ti}_{1-\mathrm{x}}\right)_{0.86} \mathrm{O}_{3}$ System Ceramics
}

\author{
Ju-hyun Yoo* and Sang-ho Lee \\ Department of Electrical Engineering, Se Myung University, Jecheon 390-711, Republic of Korea
}

(Received July 1 2009, Revised July 29 2009, Accepted August 14 2009)

In this study, in order to develop compositions of ceramics suitable for piezoelectric actuator and ultrasonic vibrator applications using low temperature sintering, multilayer, PMN-PNN-PZT ceramics were fabricated using $\mathrm{Li}_{2} \mathrm{CO}_{3}$ and $\mathrm{Na}_{2} \mathrm{CO}_{3}$ as sintering aids. Their structural, piezoelectric and dielectric characteristics were investigated according to the $\mathrm{Zr} / \mathrm{Ti}$ ratio. As the $\mathrm{Zr} / \mathrm{Ti}$ ratio increased, the electromechanical coupling factor $\mathrm{k}_{\mathrm{p}}$ and piezoelectric constant $\mathrm{d}_{33}$ and the mechanical quality factor $\mathrm{Q}_{\mathrm{m}}$ all increased with $\mathrm{Zr} / \mathrm{Ti}$ ratio and then decreased after the ratio exceeded 50/50. At the ratio of $\mathrm{Zr} / \mathrm{Ti}=49 / 51$ and sintering temperature of $900^{\circ} \mathrm{C}$; the density, electromechanical coupling factor $\mathrm{k}_{\mathrm{p}}$, dielectric constant $\varepsilon_{\mathrm{f}}$, piezoelectric $\mathrm{d}_{33}$ constant and mechanical quality factor $\mathrm{Q}_{\mathrm{m}}$ all showed the optimum values of $7.900 \mathrm{~g} / \mathrm{cm}^{3}, 0.576,856,312 \mathrm{pC} / \mathrm{N}, 1,326$, respectively. These property values are very suitable for multilayer ceramics actuator applications.

Keywords: Multilayer piezoelectric actuator, Sintering aids, Electromechanical coupling factor $\left(\mathrm{k}_{\mathrm{p}}\right)$, Mechanical quality factor $\left(Q_{m}\right)$

\section{INTRODUCTION}

In general, $\mathrm{Pb}(\mathrm{ZrTi}) \mathrm{O}_{3}$ system ceramics should be sintered at high temperatures i.e. more than $1200^{\circ} \mathrm{C}$ in order to obtain complete densification[1]. Accordingly, because of their high sintering temperature, environmental pollution due to the evaporation of $\mathrm{PbO}$ and the use of expansive $\mathrm{Pd}$ rich $\mathrm{Ag} / \mathrm{Pd}$ internal electrodes in the case of the manufacture of multilayer ceramic actuators are indispensable[2]. Also, the loss of $\mathrm{PbO}$ and the resultant variation in composition greatly affect the piezoelectric characteristics of the specimens. Therefore, it is necessary to adjust the vapor phase equilibrium of $\mathrm{PbO}$ between the ceramic to be sintered and the powder atmosphere in which the ceramics is embedded. On the other hand, in order to reduce the sintering temperature at which satisfactory densification could be obtained, various kinds of material processing methods such as the 2-stage calcination method, hot pressing, high energy mill, liquid phase sintering, and the use of ultra fine powder have been performed. Among these methods, liquid phase sintering is basically an effective method for aiding densification of specimens at low sintering temperatures. The calcination process is also important for aiding densification. The MPB (Morphotrophic Phase Boundary) region of PZT ceramics systems showed excellent piezoelectric and dielectric characteristics due to the ease of domain motion and polarizability[3]. It has been reported that compositions near MPB of the PMNPZT, PNN-PZT and PMN-PNN-PZT systems demonstrated excellent piezoelectric properties for actuator and sensor applications $[1,2,4,5]$. Nevertheless, these piezoelectric properties significantly weaken when the composition component of them moves away from the MPB. Also, the MPB region in the PZT system can be significantly changed by alteration of the component ratios and by added impurities.

*Author to whom corresponding should be addressed: electronic mail: juhyun57@semyung.ac.kr
Hence, in this study, from these viewpoints, ceramic samples of compositions in the MPB region showed high electromechanical coupling factor $\left(\mathrm{k}_{\mathrm{p}}\right)$ and piezoelectric constant $\left(\mathrm{d}_{33}\right)$ values suitable for multilayer actuator applications $\mathrm{Pb}\left(\mathrm{Mn}_{1 / 3} \mathrm{Nb}_{2 / 3}\right) \mathrm{O}_{3}-\mathrm{Pb}\left(\mathrm{Ni}_{1 / 3} \mathrm{Nb}_{2 / 3}\right) \mathrm{O}_{3}-\mathrm{Pb}(\mathrm{Zr}, \mathrm{Ti}) \mathrm{O}_{3}$ (abbreviated as PMN-PNN-PZT) ceramics were fabricated using 2-stage calcination method and $\mathrm{Li}_{2} \mathrm{CO}_{3}, \mathrm{Na}_{2} \mathrm{CO}_{3}$ and $\mathrm{ZnO}$ as sintering aids and their piezoelectric and dielectric properties were investigated according to the ratio of $\mathrm{Zr} / \mathrm{Ti}$ and sintering temperature.

\section{EXPERIMENTS}

The specimens were manufactured using a conventional mixed oxide process. The compositions used in this study were as follows;

$\mathrm{Pb}\left(\mathrm{Mn}_{1 / 3} \mathrm{Nb}_{2 / 3}\right)_{0.02}\left(\mathrm{Ni}_{1 / 3} \mathrm{Nb}_{2 / 3}\right)_{0.12}\left(\mathrm{Zr}_{\mathrm{x}} \mathrm{Ti}_{1-\mathrm{x}}\right)_{0.86} \mathrm{O}_{3}+\mathrm{MnO}_{2}+$ $\mathrm{Fe}_{2} \mathrm{O}_{3}+\mathrm{CuO}+$ Sintering aids $\left(\mathrm{Li}_{2} \mathrm{CO}_{3}, \mathrm{Na}_{2} \mathrm{CO}_{3}\right.$ and $\left.\mathrm{ZnO}\right)$ $(\mathrm{x}=0.48,0.49,0.50,0.51,0.52)$

The raw materials, $\mathrm{ZrO}_{2}, \mathrm{TiO}_{2}, \mathrm{MnO}_{2}, \mathrm{NiO}, \mathrm{Fe}_{2} \mathrm{O}_{3}, \mathrm{CuO}$ and $\mathrm{Nb}_{2} \mathrm{O}_{5}$ for the given composition were weighted by mole ratio and the powders were ball-milled for $24 \mathrm{~h}$. After drying, they were calcined at $1,100^{\circ} \mathrm{C}$ for $4 \mathrm{~h}$. Thereafter, $\mathrm{PbO}$ was added and ball-milled again. After drying, they were calcined at $750^{\circ} \mathrm{C}$ for $2 \mathrm{~h}$. Thereafter, and sintering aids such as $\mathrm{Li}_{2} \mathrm{CO}_{3}, \mathrm{Na}_{2} \mathrm{CO}_{3}$ and $\mathrm{ZnO}$ were added and ballmilled again. A polyvinyl alcohol (PVA: $5 \mathrm{wt} \%$ aqueous solution) was added to the dried powders. The powders were molded at a pressure of $1,000 \mathrm{~kg} / \mathrm{cm}^{2}$ in a mold which had a diameter of $21 \mathrm{~mm}$, burned out at $600^{\circ} \mathrm{C}$ for $3 \mathrm{~h}$, and then sintered at 870,900 and $930^{\circ} \mathrm{C}$ for $2 \mathrm{~h}$. For the measurement of piezoelectric characteristics, the specimens were polished to $1 \mathrm{~mm}$ thickness and then electrodeposited with $\mathrm{Ag}$ paste. Poling was carried out at $120^{\circ} \mathrm{C}$ in a silicon oil bath by applying fields of $30 \mathrm{kV} / \mathrm{cm}$ for $30 \mathrm{~min}$. All the samples were aged for $24 \mathrm{~h}$ prior to measurement of the piezoelectric and dielectric properties.For the investigation of dielectric properties, the capacitance was measured at $1 \mathrm{kHz}$ 


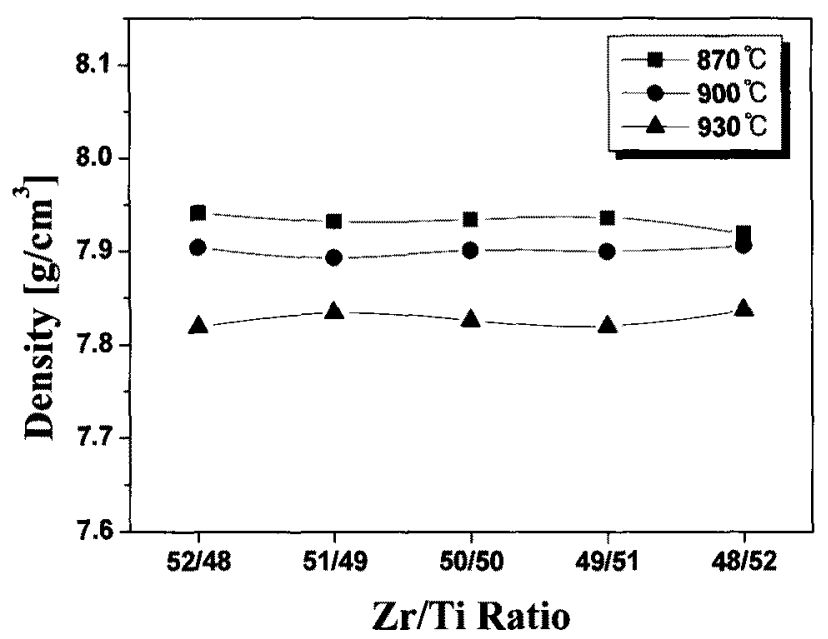

Fig. 1. Density of specimens as a function of the $\mathrm{Zr} / \mathrm{Ti}$ ratio and sintering temperature.

using an LCR meter (ANDO AG-4034) and er was calculated. For investigation of piezoelectric properties, the resonant and anti-resonant frequencies were measured by an Impedance Analyzer (Agilent 4294A) according to the IEEE standard and then the $\mathrm{kp}$ and $\mathrm{Qm}$ were calculated.

\section{RESULTS AND DISCUSSION}

Figure 1 shows density of specimens as a function of the $\mathrm{Zr} / \mathrm{Ti}$ ratio and sintering temperature. The variation of density did not show significant change as a function of $\mathrm{Zr} / \mathrm{Ti}$ ratio. Furthermore, all the composition ceramics could be sintered even the sintering temperature of $870^{\circ} \mathrm{C}$ by a $2-$ stage calcination method and the addition of sintering aids. However, entire specimens sintered at $930^{\circ} \mathrm{C}$ showed low density values due to the over-firing effect.

Figure 2 shows the microstructure of specimens as a function of the $\mathrm{Zr} / \mathrm{Ti}$ ratio at the sintering temperature of $900^{\circ} \mathrm{C}$. The grain size also did not show a large change.

Figure 3 shows X-ray diffraction patterns of specimens as a function of the $\mathrm{Zr} / \mathrm{Ti}$ ratio at a sintering temperature of $900^{\circ} \mathrm{C}$. The entire specimen showed a perovskite structure including a secondary phase. With increasing $\mathrm{Zr} / \mathrm{Ti}$ ratio, the lattice structure was changed from a tetragonal to rhombohedral form. As can be seen from the $(002)$ and (200) peaks of the X-ray diffraction patterns, it is evident that the crystal structure of the specimens changes from a tetragonal phase to rhombohedral phase, and the MPB appeared at the vicinity of the ratio of $\mathrm{Zr} / \mathrm{Ti}=50 / 50$.

Figure 4 shows the $k_{p}$ of specimens as a function of the $\mathrm{Zr} / \mathrm{Ti}$ ratio and sintering temperature. $\mathrm{k}_{\mathrm{p}}$ rapidly increased rapidly up to the ratio of $\mathrm{Zr} / \mathrm{Ti}=50 / 50$, and thereafter decreased. This behavior can be confirmed by the fact that $\mathrm{k}_{\mathrm{p}}$ and $\mathrm{Q}_{\mathrm{m}}$ generally show a maximum value and a minimum value at MPB due to the various poling directions and easy domain wall motion, respectively[3]. At a sintering temperature of $900^{\circ} \mathrm{C}, \mathrm{k}_{\mathrm{p}}$ showed a maximum value of 0.598 .

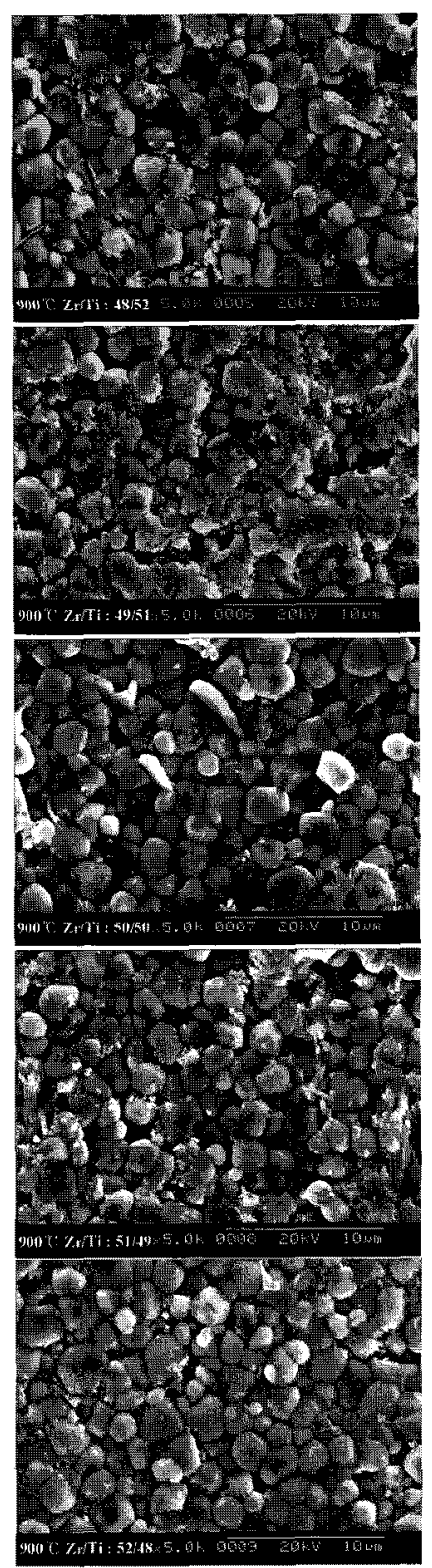

Fig. 2. Microstructure of specimens as a function of the $\mathrm{Zr} / \mathrm{Ti}$ ratio.

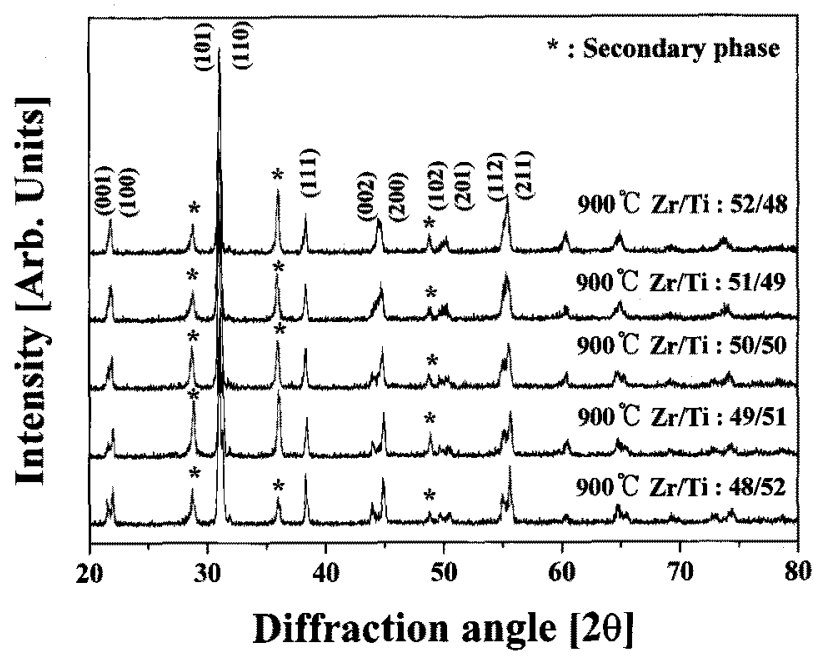

Fig. 3. X-ray diffraction pattern of specimens as a function of the $\mathrm{Zv} / \mathrm{Ti}$ ratio. 


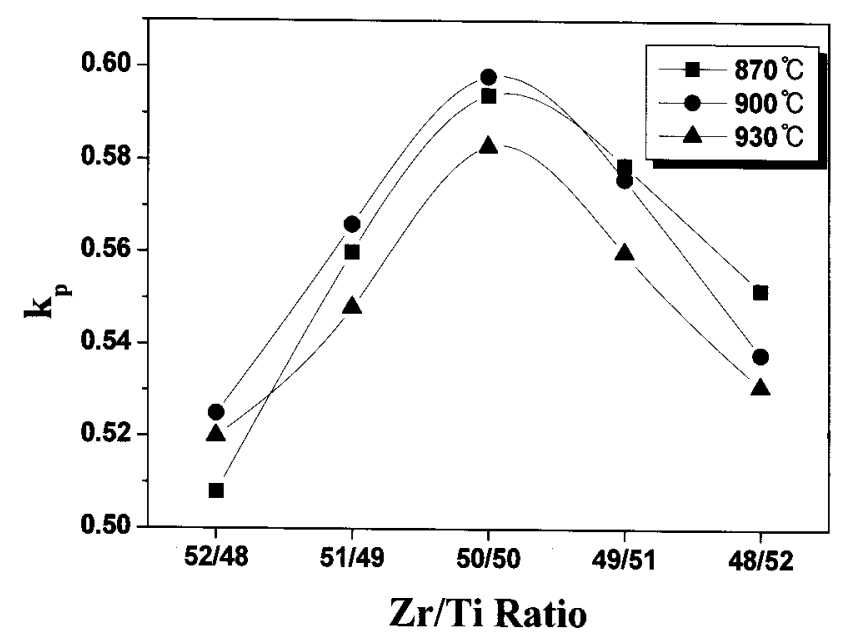

Fig. 4. $k_{p}$ of specimens as a function of the $\mathrm{Zr} / \mathrm{Ti}$ ratio and sintering temperature.

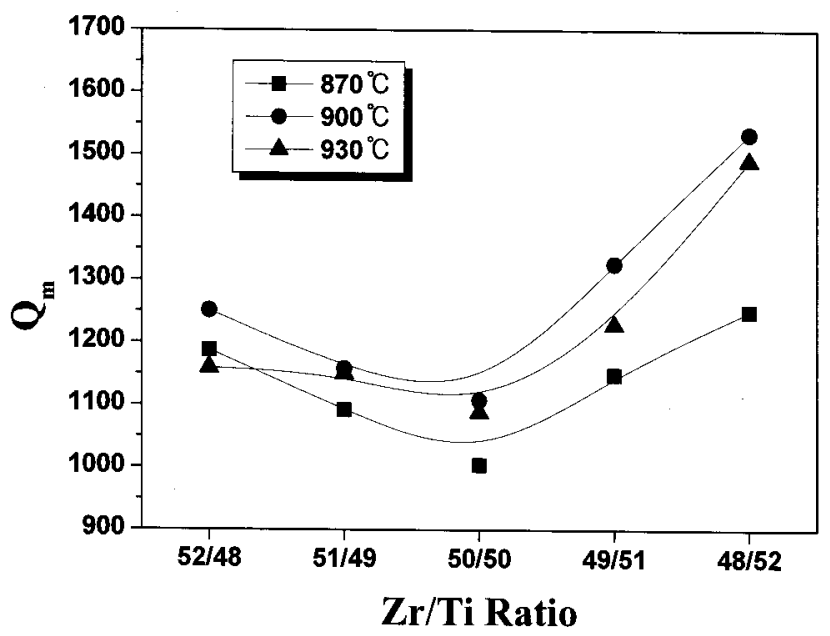

Fig. 5. $\mathrm{Q}_{\mathrm{m}}$ of specimens as a function of the $\mathrm{Zr} / \mathrm{Ti}$ ratio and sintering temperature.

Figure 5 shows the $\mathrm{Q}_{\mathrm{m}}$ of specimens as a function of the $\mathrm{Zr} / \mathrm{Ti}$ ratio and sintering temperature. The variation of $\mathrm{Q}_{\mathrm{m}}$ showed the opposite properties to $\mathrm{k}_{\mathrm{p}}$, and a minimum value of $\mathrm{Q}_{\mathrm{m}}$ appeared at the ratio of $\mathrm{Zr} / \mathrm{Ti}=50 / 50$. This result can also can be explained by the piezoelectric characteristics in the MPB region as explained in the above $k_{p}$ analysis.

Figure 6 and 7 show $\varepsilon_{\mathrm{r}}$ and $\mathrm{d}_{33}$ for the specimens as a function of the $\mathrm{Zr} / \mathrm{Ti}$ ratio and sintering temperature, respectively. The variations of $\varepsilon_{\mathrm{r}}$ and also $\mathrm{d}_{33}$ coincided with the trend of $\mathrm{k}_{\mathrm{p}}$. These results can be illustrated by the fact that the coexistence of the tetragonal and rhombohedral phases in the MPB region readily aids the polarizability and domain rotation of the specimens.

\section{CONCLUSIONS}

In this study, in order to develop low loss and low temperature sintered ceramics for multilayer actuator application, $\mathrm{Pb}\left(\mathrm{Mn}_{1 / 3} \mathrm{Nb}_{2 / 3}\right) \mathrm{O}_{3}-\mathrm{Pb}\left(\mathrm{Ni}_{1 / 3} \mathrm{Nb}_{2 / 3}\right) \mathrm{O}_{3}-\mathrm{Pb}(\mathrm{Zr}$, Ti $) \mathrm{O}_{3}$ ceramics were fabricated using a 2 -stage calcination method.

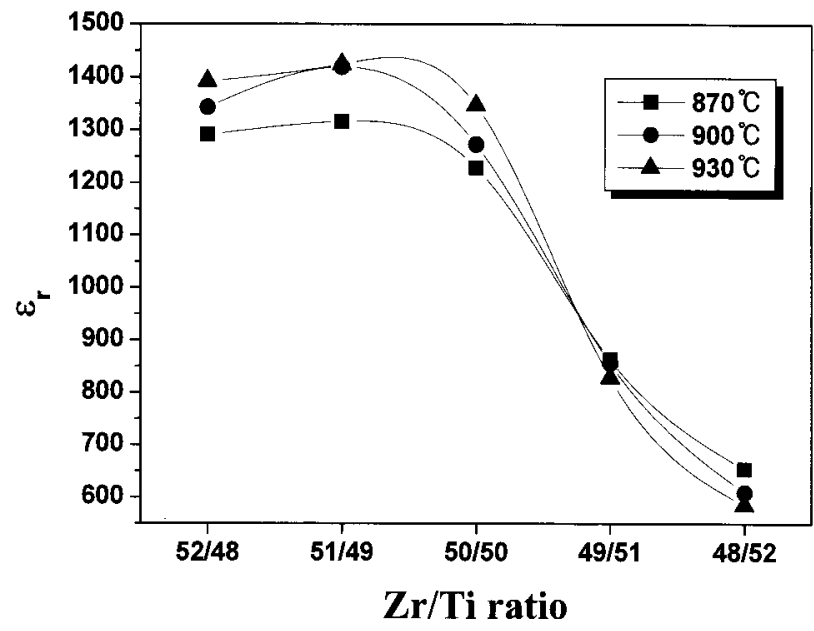

Fig. 6. $\varepsilon_{\mathrm{r}}$ of specimens as a function of the $\mathrm{Zr} / \mathrm{Ti}$ ratio and sintering temperature.

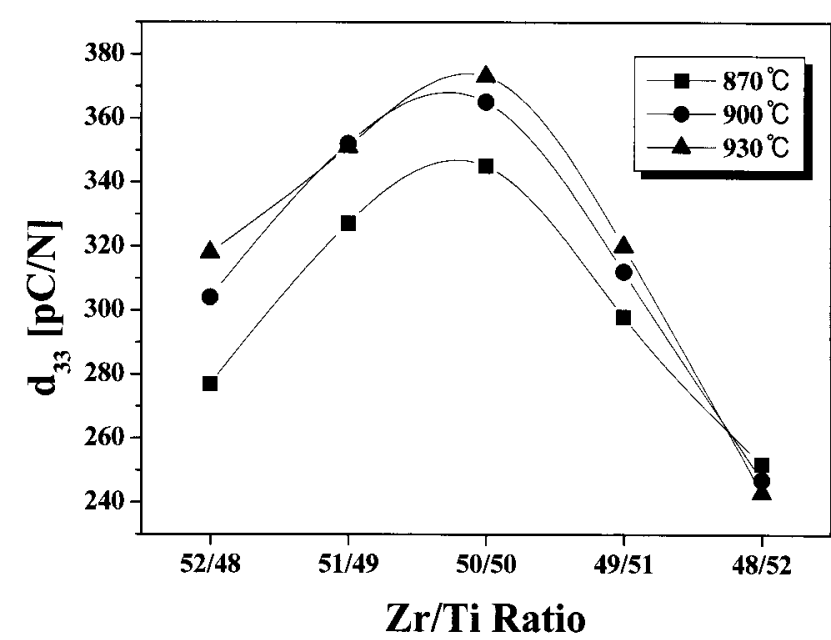

Fig. 7. $\mathrm{d}_{33}$ of specimens as a function of the $\mathrm{Zr} / \mathrm{Ti}$ ratio and sintering temperature.

Table 1. Physical characteristics of the specimens.

\begin{tabular}{|c|c|c|c|c|c|c|c|c|}
\hline $\begin{array}{c}\text { Sintering } \\
\text { Temp. }[\mathrm{C}]\end{array}$ & $\begin{array}{l}\mathrm{Zr} / \mathrm{Ti} \\
\text { Ratio }\end{array}$ & $\begin{array}{l}\text { Density } \\
{\left[\mathrm{g} / \mathrm{cm}^{3} \mid\right.}\end{array}$ & $\varepsilon_{x}$ & $k_{p}$ & $\mathrm{Q}_{\mathrm{m}}$ & $\underset{[\mathrm{pC} / \mathrm{N}]}{\mathbf{d}_{33}}$ & $\begin{array}{c}\text { Grain } \\
\text { Sizz }|\mu \mathrm{m}|\end{array}$ & $\begin{array}{c}\text { Tetragonalit } \\
\text { [e/a] }\end{array}$ \\
\hline \multirow{5}{*}{870} & $52 / 48$ & 7.941 & 1291 & 0.508 & 1188 & 277 & & \\
\hline & $51 / 49$ & 7.932 & 1316 & 0.560 & 1092 & 327 & & \\
\hline & $50 / 50$ & 7.934 & 1229 & 0.594 & 1004 & 345 & & \\
\hline & $49 / 51$ & 7.936 & 863 & 0.579 & 1149 & 298 & & \\
\hline & $48 / 52$ & 7.919 & 654 & 0.552 & 1250 & 252 & & \\
\hline \multirow{5}{*}{900} & $52 / 48$ & 7.904 & 1343 & 0.525 & 1251 & 304 & 2.253 & 1.0234 \\
\hline & $51 / 49$ & 7.893 & 1419 & 0.566 & 1158 & 352 & 2.289 & 1.0224 \\
\hline & $50 / 50$ & 7.901 & 1273 & 0.598 & 1108 & 365 & 2.230 & 1.0186 \\
\hline & $49 / 51$ & 7.900 & 856 & 0.576 & 1326 & 312 & 2.551 & 1.0017 \\
\hline & $48 / 52$ & 7.906 & 609 & 0.538 & 1534 & 247 & 2.348 & 1.0000 \\
\hline \multirow{5}{*}{930} & $52 / 48$ & 7.819 & 1392 & 0.520 & 1159 & 318 & & \\
\hline & $51 / 49$ & 7.834 & 1424 & A. 548 & 1150 & 351 & & \\
\hline & $50 / 50$ & 7.826 & 1347 & 0.583 & 1088 & 373 & & \\
\hline & $49 / 51$ & 7.820 & 828 & 0.560 & 1228 & 320 & & \\
\hline & $48 / 52$ & 7,837 & 585 & 0.531 & 1491 & 243 & & \\
\hline
\end{tabular}

In addition $\mathrm{Li}_{2} \mathrm{CO}_{3}, \mathrm{Na}_{2} \mathrm{CO}_{3}$ and $\mathrm{ZnO}$ were used as sintering aids and their piezoelectric and dielectric properties were investigated according to the ratio of $\mathrm{Zr} / \mathrm{Ti}$ and sintering temperature. 
1. All the specimens showed a satisfactorily high density at all temperatures due to the use of the 2-stage calcination method and other sintering aids.

2. All the specimens displayed a perovskite structure including a secondary phase.

3. As the $\mathrm{Zr} / \mathrm{Ti}$ ratio decreased, the crystalline structure was changed from a rhombohedral to tetragonal phase.

4. At the ratio of $\mathrm{Zr} / \mathrm{Ti}=49 / 51$ and sintering temperature of $900^{\circ} \mathrm{C}$, the density, electromechanical coupling factor $\mathrm{k}_{\mathrm{p}}$, dielectric constant $\varepsilon_{\mathrm{T}}$, piezoelectric $\mathrm{d}_{33}$ constant and mechanical quality factor $\mathrm{Q}_{\mathrm{m}}$ all showed the optimum value of $7.900 \mathrm{~g} / \mathrm{cm}^{3}, 0.576,856,312 \mathrm{pC} / \mathrm{N}, 1326$, respectively, very suitable for the intended multilayer ceramics actuator applications.

In comparison with previous work, the density and mechanical quality factor of the specimens are enhanced. However the electromechanical coupling factor and dielectric properties of the specimens were adversely influenced by the MPB region effect[6].

\section{ACKNOWLEDGEMENTS}

This work was supported by 2008 Semyung University Research Year Program and grant No.(R01-2006-00010120-0) from the Basic Research Program Korea Science and Engineering Foundation of Ministry of Science \& Technology.

\section{REFERENCES}

[1] Y. Jeong, J. Yoo, S. Lee, and J. Hong, Sens. Actuators, A 135, 215 (2007).

[2] J. Yoo, C. Lee, Y. Jeong, K. Chung, D. Lee, and D. Paik, Mater. Chem. Phys. 90, 386 (2005).

[3] Y. Xu, Ferroelectric Materials and Their Application, (Elsevier Science Publishers, London, 1991), p. 125.

[4] G. Robert, M. Demartin, and D. Damjanovic, J. Am. Ceram. Soc. 81, 749 (1998)

[5] R. Zuo, L. Li, X. Hu, and Z. Gui, Mater. Res. Bull. 36, 2111 (2001).

[6] S. Lee, J. Yoo, H. Song, S. Lee, and K. Choi, ISAF-2007, (2007). 